\title{
ТЕКТОНИКА ЗЕМЛИ ФРАНЦА-ИОСИФА И ПРИЛЕГАЮЩЕГО ШЕЛЬФА
}

\section{Шипилов Э.В. ${ }^{1}$, Шкарубо С.И. ${ }^{2}$, Митяев М.В. ${ }^{3}$, Козлова О.В.}

${ }^{1}$ Полярный геофизический институт, Мурманск, shipilov@pgi.ru

${ }^{2}$ Морская арктическая геологоразведочная экспедииия, Мурманск

${ }^{3}$ Мурманский морской биологический институт КНЦ РАН, Мурманск

В современном структурном плане арх. Земля Франца-Иосифа (ЗФИ) представляет собой обособленное сводово-блоковое поднятие земной коры в виде окраинно-континентального плато разобщенного многочисленными каналами и проливами на 192 острова. В очертании островов и конфигурации проливов весьма отчетливо просматривается их подчиненность двум основным системам линеаментов СВ и СЗ ориентировки, что указывает на их взаимосвязь с соответствующими группами разломов и нарушений (рис. 1).

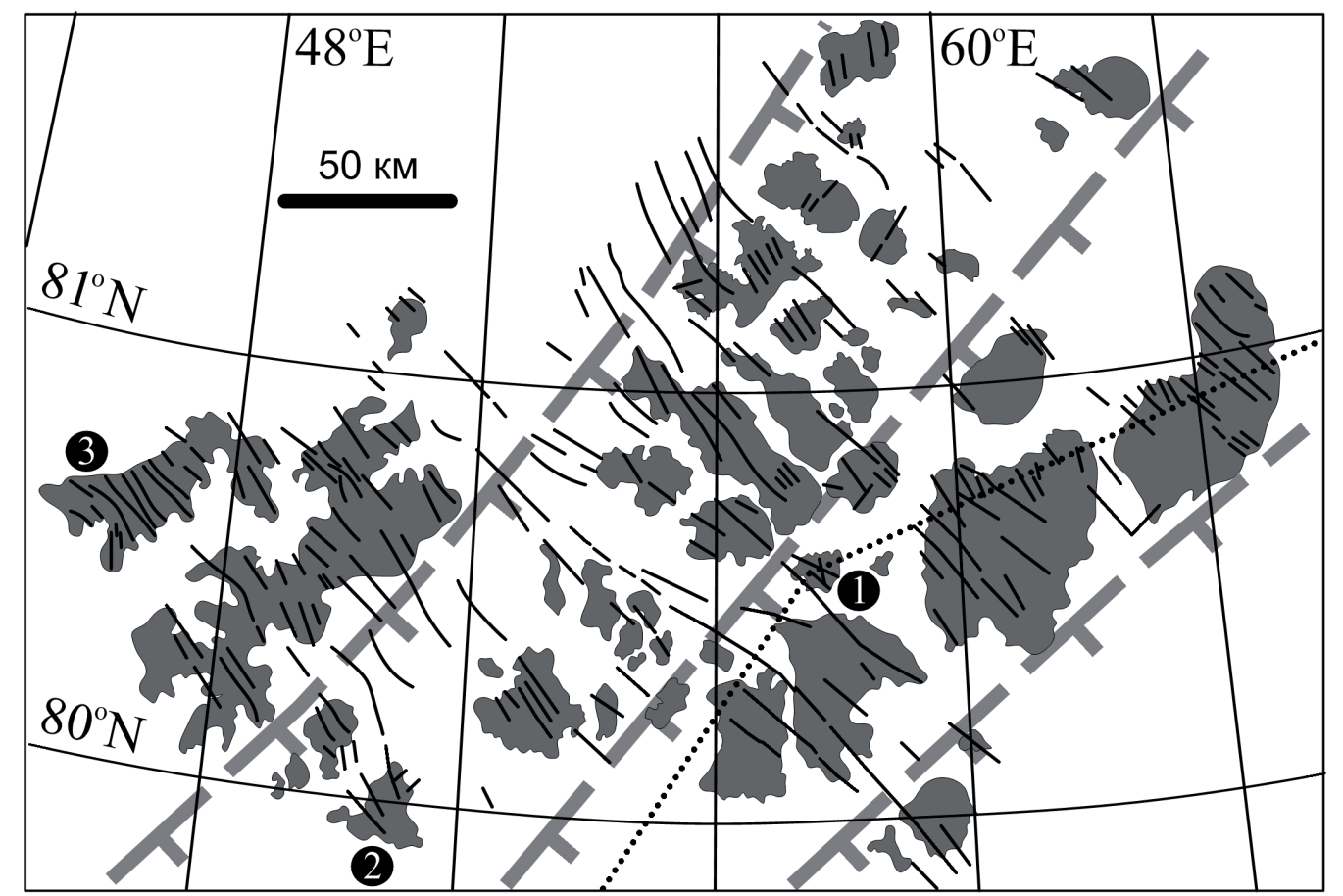

Рис. 1. Схема размещения линейных магнитных аномалий и палеозойских разломов архипелага ЗФИ.

Толстая пунктирная линия с зубцами - разломы палеозойского заложения; тонкие линии - линеаменты аномалий магнитного поля, ассоциируемые с дайками [11]; точечная пунктирная линия - положение профиля (рис. 2). Цифры в кружках - острова, упоминаемые в тексте: 1 - о. Хейса, 2 - о. Нортбрук, 3 - о. Земля Александры.

Проведенный нами комплексный анализ геолого-геофизических данных в субширотной полосе, пересекающей ЗФИ от желоба Франц Виктория до желоба Св. Анны, позволил изучить структурно-тектонические элементы поднятия ЗФИ северо-восточной ориентировки.

В глубинной структуре архипелага, помимо двух трогов ограничивающих его с запада и востока, обнаруживается достаточно глубокий (до 8-10 км) грабен в зоне пролива Австрийский канал. Он выражен главным образом в отложениях среднего-верхнего палеозоя, а вверх по разрезу в мезозойских отложениях, преобразуется в зональную бортовую сбросово-флексурную зону расположенного к востоку триасового прогиба. По глубинной структуре вдоль профиля весь массив ЗФИ разделен грабенообразным прогибом и сопровождающими его разломами и на две крупных глыбы (все СВ простирания), каждая из которых имеет сложную блоково-ступенчатую структуру $[4,5]$. Судя по морфологии фундамента, глыбы погружаются с северо-запада на юго-восток по направлению к Восточно-Баренцевскому мегапрогибу, что согласуется с моделью его рифтогенного развития в позднем девоне-карбоне. 
На фоне рассмотренных элементов тектоники СВ ориентировки получил развитие структурный план с С3 трендами, созданный в юрско-меловую тектономагматическую эпоху связанную с доминирующим рифтогенно-спрединговым режимом обусловленным деструктивным воздействием плюма на литосферу Арктики $[6,7]$. Особенностью юрско-мелового структурного плана ЗФИ является не только его ортогональная наложенность на палеозойскую зональность, но и секущий характер по отношению к подстилающим структурам, нарушающий их сплошность. Эта специфика тектоники отчетливо отражена в рисунке аномалий магнитного поля. Архипелаг и прилегающий шельф в магнитном поле представлен ярко выраженными положительными полосовыми аномалиями на отрицательном фоне все той же СЗ ориентировки $[6,7]$. Эти аномалии отчетливо совпадают с дайками базальтоидов различной мощности и протяженности, штокообразными телами и подводящими магматическими каналами, аккомодированными преимущественно к зонам разломов.

В работах [6,7] было высказано мнение, что акцентированная локализация даек о. Хейса в срединной зоне раздела архипелага, их субпараллельное С3 простирание, сближенные значения возрастов и отражение в полосовом характере магнитного поля указывают на существование на временном отрезке валанжин-баррем (ранний мел) довольно отчетливо проработанной тектонической полосы растяжения, что предполагает наличие в этой зоне рифтогенных структур.

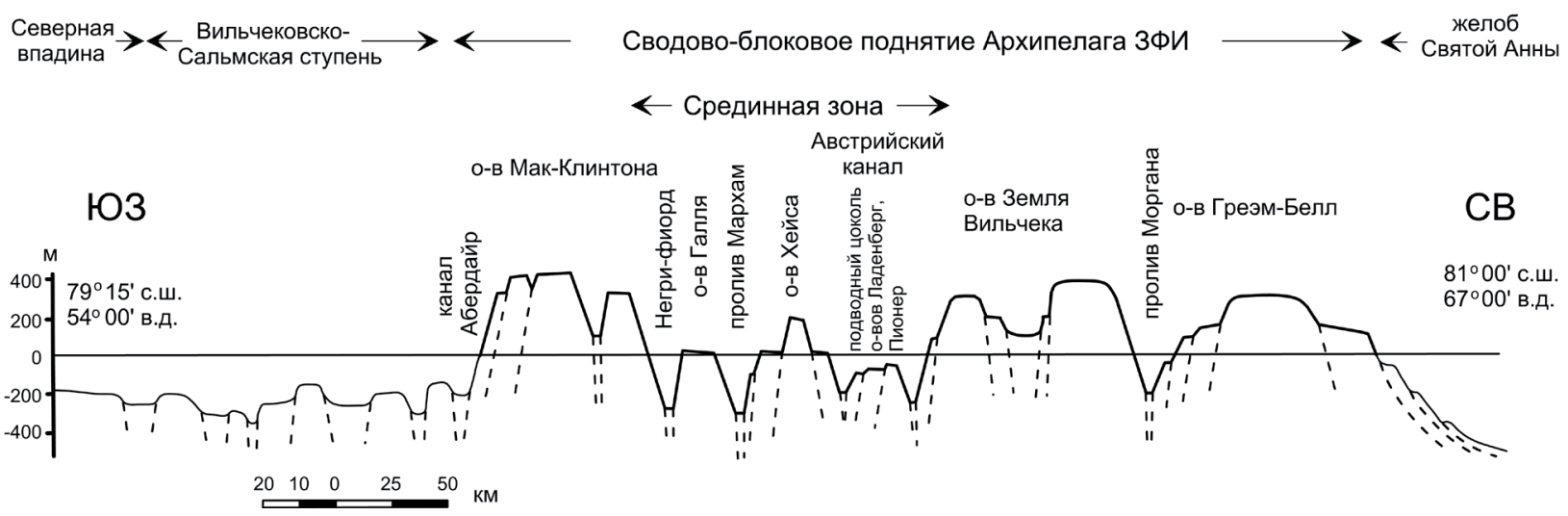

Рис. 2. Структурно-геоморфологический профиль через арх. Земля Франца-Иосифа. Составлен на основе Bathymetric Map of the Franz Josef Land Area [12]. Положение на рис. 1.

Ввиду отсутствия сейсморазведочных данных на островах архипелага, по результатам батиметрических и геоморфологических исследований $[2,12]$ нами был составлен структурногеоморфологический профиль СВ ориентировки вкрест простирания юрско-мелового структурного плана (рис. 2). Несмотря на экзарационные и эрозионные преобразования рельефа, гравитационнооползневую тектонику на профиле между о-вами Мак-Клинтона и Земля Вильчека весьма отчетливо отображается рифтоподобная долина, представленная сочетанием грабенов и горстов, практически симметричная относительно поднятия о. Хейса. Это дает основание говорить об унаследованном характере новейшего рельефа и подтверждает наш вывод о срединном положении этой зоны растяжения земной коры на архипелаге $[6,7]$. Радиологическое датирование базальтов из даек о. Хейса $[1,7]$, как центра рифтовой зоны, показывает, что осевое растяжение происходило в интервале от 138 до 124 млн. лет (начало раннего мела: валанжин-баррем).

Достоверные сведения о наличии структур растяжения в мезозойских комплексах осадочного чехла были получены в результате сейсморазведочных работ (МАГЭ) на южном шельфовом обрамлении ЗФИ $[3,9,10]$. Здесь закартированы различные по размерам грабены и многочисленные проявления базальтоидного магматизма в виде даек, штоков и силлов (рис. 3,4$)$.

Сейсмическим разрезом МОВ ОГТ (рис. 3) в юрско-меловом интервале осадочного чехла зафиксирован грабен с размером в поперечнике около 50 км. Вертикальная амплитуда смещения по ограничивающим его разломам наиболее ясно отмечается по опорным отражающим сейсмическим 


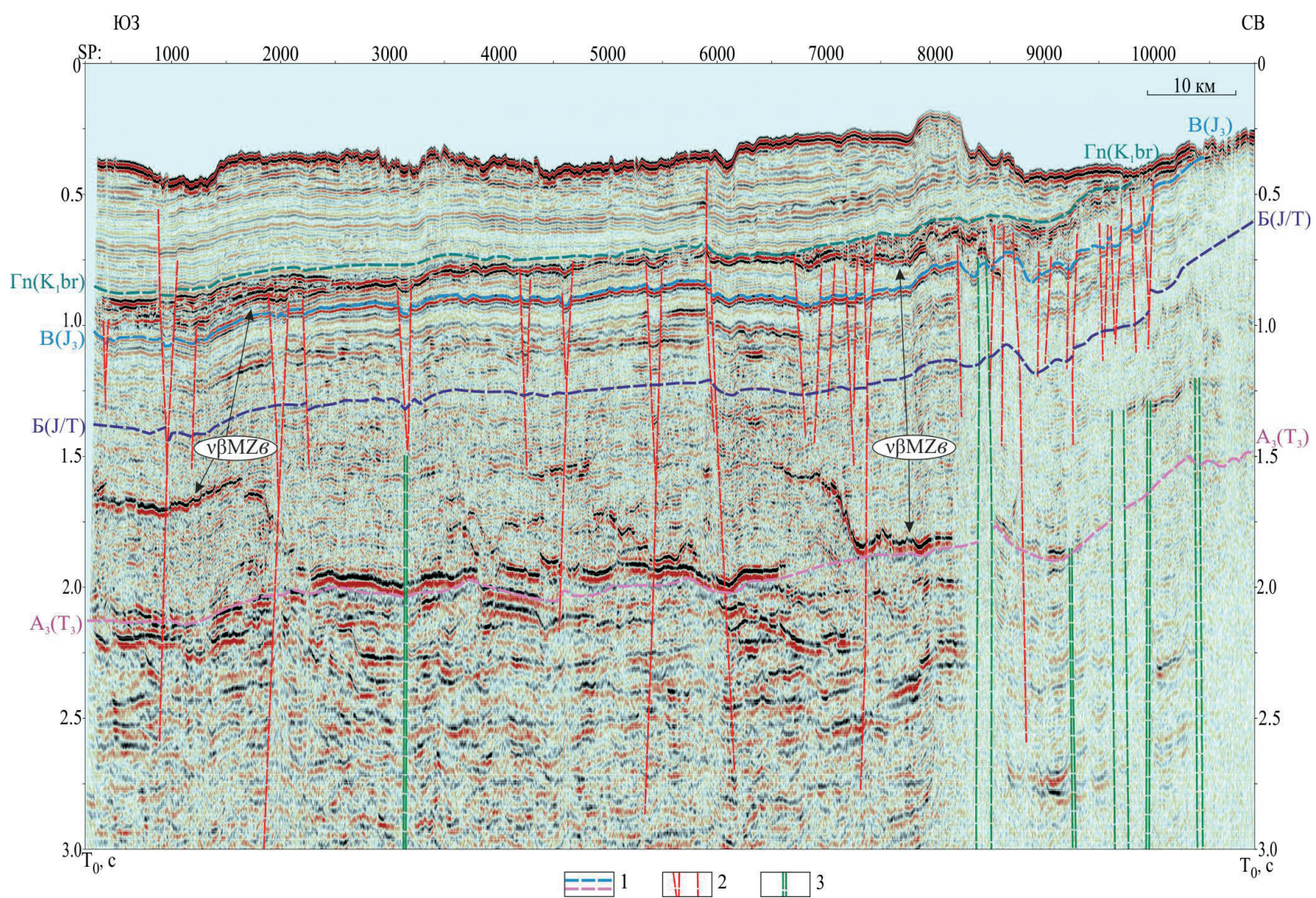

Рис. 3. Сейсмический разрез (МАГЭ) осадочного чехла южного шельфового обрамления арх. ЗФИ (положение на рис.4). 1- основные сейсмические отражающие горизонты, 2 - разломы, 3 - дайки и подводящие магматические каналы.

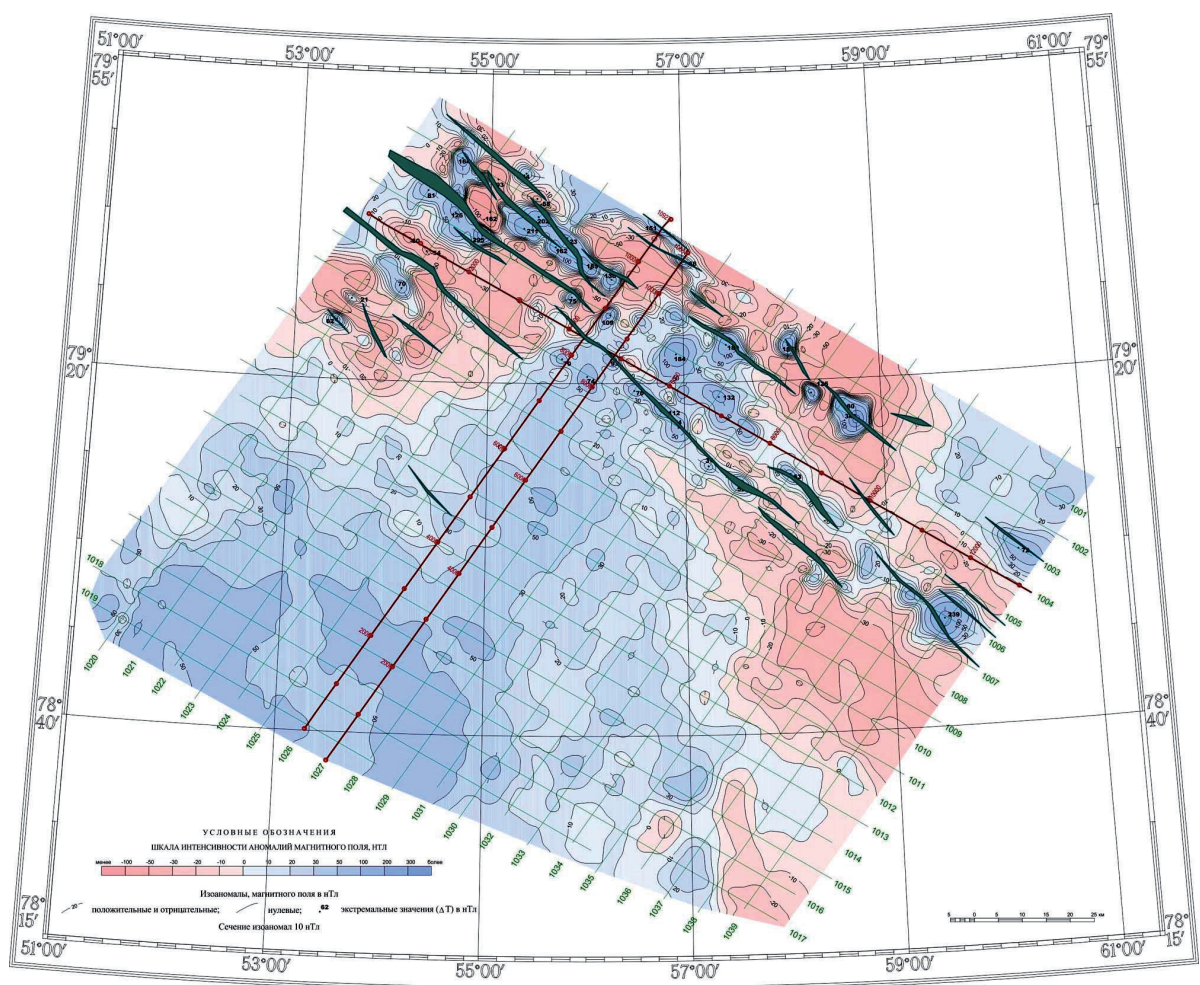

Рис. 4. Карта аномального магнитного поля южного шельфового обрамления ЗФИ и расположение даек, выделенных по сейсмическим данным. Изаномалы магнитного поля - нТл, точки с цифрами - экстремальные значения магнитного поля. 
горизонтам начиная от подошвы юры и затухает в апт-альбских отложениях. Практически под центральной частью грабена обнаруживается вертикальная «засвеченная» зона (отсутствие отражений), интерпретируемая как подводящий канал магматогенного вещества, который венчается линзой вулканогенно-осадочного материала либо туфобрекчий. Фиксированное положение этой линзы в разрезе и связанный с ней интенсивный отражающий горизонт, тянущийся южнее, указывают на предбарремское время проявления этого магматического события, как и основной фазы образования грабена.

Особенности строения, подъем комплексов чехла в сторону ЗФИ позволяют говорить о том, что грабен был сформирован в условиях куполообразного воздымания и тектонического расчленения земной коры под воздействием плюма. В этой связи его можно охарактеризовать не только как структуру растяжения, но и проседания. Серия более мелких, шириной первые километры, грабенов с V-образным ограничением разломами отмечается и южнее по разрезу.

Описанный грабен укладывается в трассированную дайками полосу С3 простирания (рис. 4), за пределами которой южнее дайки не прослеживаются, о чем свидетельствует и характер аномального магнитного поля. Эта полоса кулисообразно расположенных даек на картах более мелкого масштаба выступает как последняя, наиболее заметная, единая слитная высокоамплитудная полосовая магнитная аномалия, простирающаяся на северо-западе к о. Нортбрук. В контексте изложенного, аналогичная тектоническая ситуация с наличием грабенов прогнозируется нами и на самом архипелаге.

Вместе с тем, следует отметить, что на шельфе имеют место единичные дайки, которые отличаются ориентировкой, что указывает, видимо, на несколько их генераций, как это имеет место на о. Хейса $[1,7]$.

Таким образом, современная блоковая структура архипелага и окружающего его шельфа обусловлена тектоническим каркасом диагональной системы разломов. Разломы северо-восточной ориентировки соотносятся с серией ступенчатых сбросов по направлению к депоцентру ВосточноБаренцевского мегабассейна на инициальном рифтогенном этапе его образования в среднепозднепалеозойское время. Наличие довольно мощного комплекса триасовых образований на архипелаге дает основание считать, что этот район входил в состав мегабассейна и являлся его бортовой зоной с соответствующими режимами и темпами осадконакопления. Разломы северо-западного направления возникли в юрско-меловое время на тектономагматическом этапе, связанном с доминирующими рифтогенно-спрединговыми процессами в Арктике под воздействием плюма. Эти разломы на архипелаге и прилегающем шельфе контролируют довольно широкую (около 400 км) полосу растяжения, представленную чередованием грабенов и горстов, сочетающихся с трассами кулисообразно размещенных даек. В результате отмеченных тектоно-геодинамических событий был создан перекрестный структурный план сводово-глыбового поднятия, активизированный в неотектоническую эпоху [8] и моделированный экзарационными и эрозионными процессами.

\section{Литература}

1. Карякин Ю.В., Шипилов Э.В. геохимическая специализация и ${ }^{40} \mathrm{AR} /{ }^{39} \mathrm{AR}-$ возраст базальтоидного магматизма островов Земля Александры, Нортбрук, Гукера и Хейса (архипелаг Земля Франца-Иосифа) // ДАН. 2009. Т. 425. № 2. С. 213-217.

2. Митяев М.В., Герасимова М.В. Геолого-тектонические, геоморфологические особенности строения и современные условия седиментации архипелага Земля Франца-Иосифа // Тр. Кольского научного центра РАН. Вып. 2. 2014. № 4 (23). С. 5-60.

3. Пискарев А.Л., Казанин Г.С., Киреев А.А. и др. Строение восточного борта Северо-Баренцевской впадины и перспективы открытия в регионе крупных месторождений нефти // Разведка и охрана недр. 2016. №1. C. 44-48.

4. Сенин Б.В., Шипилов Э.В., Матишов Г.Г., Тарасов Г.А. Новейшая тектоника архипелага Земля ФранцаИосифа и прилегающего шельфа. В сб.: Биологические процессы и эволюция морских экосистем в условиях морского перигляциала. Мурманск: Изд-во «Русская Лапландия», 1996. С. 63-64.

5. Твердые полезные ископаемые архипелагов и островов арктической континентальной окраины Евразии / Гл. ред. В.Д. Каминский. СПб., ВНИИОкеангеология, 2010, 336 с. 
6. Шипилов Э.В. Базальтоидный магматизм и сдвиговая тектоника Арктической континентальной окраины Евразии в приложении к начальному этапу геодинамической эволюции Амеразийского бассейна // Геология и геофизика. 2016. Т. 57. № 12. С. 2115-2142.

7. Шипилов Э.В., Карякин Ю.В. Дайки острова Хейса (архипелаг Земля Франца-Иосифа): тектоническая позиция и геодинамическая интерпретация // ДАН. 2014. Т. 457. № 3. С. 327-331.

8. Шипилов Э.В., Тюремнов В.А., Глазнев В.Н., Голубев В.А. Палеогеографические обстановки и тектонические деформации Баренцевоморской континентальной окраины в кайнозое // ДАН. 2006. Т.407. № 3. С. 378-383.

9. Шкарубо С.И., Шипилов Э.В. Тектоника Западно-Арктической платформы // Разведка и охрана недр. 2007. № 9. С. 32-47.

10. Шлыкова В.В., Величко Б.М., Павлов С.П., Зуйкова О.Н. Прогноз развития объектов возможного УВнакопления на Северо-Баренцевском шельфе // Разведка и охрана недр. 2017. №10. С 39-48.

11. Buchan K.L., Ernst R.E. In: Hanski E., Mertanen S., Ramo T., Vuollo J. (Eds.), Dyke Swarms: Time Markers of Crustal Evolution. Balkema Publishers, Rotterdam. 2006 //html: April 2006 LIP of the Month Large Igneous Provinces Commission.

12. Matishov G.G., Cherkis N.S., Vermillion M.S., Forman S.L. Bathymetric Map of the Franz Josef Land Area. Scale 1:500 000. Colorado: Geol. Soc. Amer., 1995. 